\title{
Social network typologies of older people: A cross-national literature review
}

\author{
Tipologias de redes sociais da população idosa: \\ Uma revisão transnacional da literatura
}

Sónia Guadalupe (https://orcid.org/0000-0003-4898-3942) ${ }^{1}$

Henrique Testa Vicente (https://orcid.org/0000-0001-5571-9168) ${ }^{2}$

${ }^{1}$ Instituto Superior Miguel Torga (ISMT), Centre for Health Studies and Research, Universidade de Coimbra. Paço das Escolas. 3004-531 Coimbra Portugal.

soniaguadalupe@gmail.com ${ }^{2}$ ISMT, Research Centre for the Study of Population, Economy and Society. Coimbra Portugal.

\begin{abstract}
This article presents an issue narrative non-systematic review about social network typologies for the older population. We analysed 18 studies with large samples from 14 countries worldwide. The position of family ties, network composition, network size, frequency of contacts and community participation are central to social network typologization in the older population. Restricted and diverse networks emerged in typologies associated, respectively, with less and more effective social support features, and are good predictors of well-being, health, mental health, social support and social participation. Cross-nationally, there is an unequal distribution of the construction of network typologies. The different typologies, that should be culturally ground$e d$, provide guidelines to intervention planning, inform social service providers about emerging needs and contribute to social policy debate.
\end{abstract}

Key words Social networks, Social support, Family, Older people
Resumo O artigo apresenta uma revisão temática e narrativa não sistemática sobre tipologias de redes sociais pessoais da população idosa. Analisámos 18 estudos com amostras grandes de 14 países. A posição dos laços familiares, a composição da rede, o tamanho, a frequência de contactos e a participação comunitária são centrais na definição dos tipos de rede nesta população. As redes restritas e diversificadas emergem nas tipologias associadas, respetivamente, a menor ou maior apoio social, e são bons indicadores do bem-estar, saúde, saúde mental, apoio social e participação social. Transnacionalmente, verifica-se uma distribuição desigual da construção de tipologias. As diferentes tipologias, que devem ser culturalmente fundadas, fornecem diretrizes para planejar a intervenção, repensar serviços sociais e planejar políticas sociais.

Palavras-chave Redes sociais, Apoio social, Família, População idosa 


\section{Introduction}

The classification of networks in typologies arises with the first conceptual approaches ${ }^{1-3}$, addressing fundamentally their interconnection or density levels, classifying mesh and union levels, differentiating them as close-knit and loose-knit ${ }^{4}$ or as cohesive and homogeneous, fragmented and dispersed networks.

We find network categorizations based on the strength of ties ${ }^{6}$, on the social roles of its members or their linkage to the focal person ${ }^{7,8}$, and on the kinship topography in urban settings ${ }^{9}$. Other typologies result from the analysis of the interaction between various node and ties properties, such as the four network models (encapsulated, selective, open, affine) proposed by Portugal ${ }^{10,11}$; the typological triad of networks (kin-dominant, nonkin-dominant and small-network) presented by Giannella and Fischer ${ }^{12}$; or the network types based on composition and potential social support (restricted, minimal family, family, weak ties, diverse) presented in the European study of Vassilev et al. ${ }^{13}$.

In the last decades, the interest in research on social networks of older people has significantly increased, dating back to the 1980s one of the first known typological proposals ${ }^{14}$. The typologies found in the literature are based on the type of ties binding individuals and organizations to each other, network morphology (size, density or composition) and its hetero/homogeneity (dominant sociological attributes of individuals). They configure a heuristic framework based on the aggregation of characteristics that we find in networks, allowing us to distinguish them from each other ${ }^{11}$, without obscuring their diversity.

In the present review, we consider age as a sociological characteristic of the population, focusing on older people. We use a narrative review with three objectives within the framework of the "Personal Social Networks of Portuguese Elderly" research project (undergoing at Research Centre for the study of Population, Economy and Society and Miguel Torga Institute of Higher Education, Portugal) that aims precisely to build a personal social network typology of the Portuguese older population: i) to review the state of the art about social network typologies devised for the older population; ii) to systematize the criterion variables employed in the construction of typologies; iii) and to analyse the methodologies used on the cross-national studies.

Specifically, the present paper aims to unveil the commonalities between the various and dispersed studies focused on elderly social network typologies and provide guidance for researchers studying this relevant issue. Additionally, we seek to identify those network types that emerge as having the highest psychosocial risk for the older population and those that may act as buffers for the impact of stressors stemming from the environment and the aging process itself.

\section{Method}

We present a narrative non-systematic review in a specific field of research, also described as an issue review $^{15}$, about social network typologies for the older population. Several bibliographic databases (Web of Science, Scopus, Google Scholar and B-On) were used, and searches were conducted for the following combined key words: social networks, personal social networks, ego-networks, ego-centred networks, typologies, network types, elderly, older people. The key words were searched in English, Portuguese and Spanish. We exclusively selected articles, books and book chapters that present the construction of an original network typology focused on the older population, using data and samples from this population segment. As some papers about older personal social networks attempt to replicate previously found typologies, those that didn't meet the originality inclusion criterion were not selected.

Other selection criteria were the relevance of research and sample size. The samples have more than 500 participants in all cases, except two with 200 and 254 respondents, included because of their innovative contributions. In addition, two selected studies used an age criterion under 60 years old $(50+$ and $55+)$. We decided to include them, taking into account the demographic specificity of the elderly population in some countries or regions, as well as the social context that the study intends to specifically inform (for example, Portugal in the context of the characteristics of southern European countries), and also because the focus of these studies was the aging process and the older population.

The temporal span of the selected published studies corresponds to a period of 29 years (1986 to 2015), but with uneven temporal distribution, probably due to the growing interest in this area: the smallest part of these studies were published in the $1980 \mathrm{~s}(10 \%), 35 \%$ arose in the $1990 \mathrm{~s}, 30 \%$ in the first decade of the XXI century, and 25\% was published in the second decade.

After systematizing the data regarding emerging typologies in the revised studies, we analysed the variables that the authors indicate as central 


\section{Results}

This literature review included 18 studies in 20 publications, analysed according to the following categories: author(s)/year; geographical location (country or region); participants (sample representativeness); methods used in typology construction and criterion variables; network type designations (Chart 1). We also present a summary of the main characteristics of the different network types each typology and the main results evidenced by the studies.

Mugford and Kendig ${ }^{16}$ categorized older' Australian networks in a study with 1,050 participants aged $60+$, based on the relation between network size and multiplexity of ties (singularly focused versus multifaceted relationships), classified as low, medium or high. Balanced networks were the most frequent, followed by intense (small and multiplex) and diffuse networks (large and uniplex), highlighting the relevance of family and marital status.

Clare Wenger ${ }^{17,18}$ establishes her typology on a longitudinal study in rural communities of North Wales, UK, exploring the nature of social network support and the implications for the use of social services in a sample of 534 individuals aged 65+ living in their own homes. Following this study, Wenger interviewed widowers on four occasions and concluded that loneliness and network type were closely associated ${ }^{19}$. In Wenger's classification $^{17,18}$, a family dependent support network is centred on close family ties, often with intergenerational cohabitation or closeness, and with peripheral relationships with friends and neighbours. These networks tend to be small and are usually held by older widows with poor health and low community involvement. A locally integrated support network is larger, made up of family members, neighbours, and local friends. This type is more frequent among older adults living in the same place for a long time and actively involved in the community. Local self-contained support networks are smaller, with low-intimacy relationships and limited contact, neighbourly relations but

few family relationships; they are associated with home-bound life and low community involvement, and are common among childless people. Wider community-focused support networks are larger, with dominant relationships with friends, some neighbours, and relatives (usually geographically distant), with some community participation. Private restricted support networks are small and are characterized by the absence of relatives and friends nearby, except for cohabitants, with minimal contact with neighbours and a low level of community involvement, being associated with couples or isolated individuals. Thiyagarajan et al. ${ }^{20}$ validated Wenger's typology ${ }^{17,18}$ with an international sample of 17,031 participants aged $65+$ from eight low and middle-income countries (India, China, Cuba, Dominican Republic, Venezuela, Mexico, Peru and Puerto Rico). When compared to the characteristics of locally integrated networks, all other types were considered non-integrated networks, associated with situations of greater social and health vulnerability. The prevalence of social support network types was similar among the different geographical locations (i.e. different countries), but differences were found between rural and urban areas.

Howard Litwin is the author of several typological proposals regarding the personal social networks of older people. Litwin ${ }^{21,22}$ defines a first network typology from a study of 254 older Soviet Jews who emigrated in Israel, aged 62+, based on interviews that mapped their structural social network before and after migration. The author agglomerated four types of networks after migration. The kin network is the most frequent in the sample, encompassing extended family members, with affective proximity, long-lasting ties, but low level of contacts and residential proximity; these networks tend to be larger than the average. The family intensive network is the smallest one, dense and intimate, composed of nuclear family and cohabitants, with long-lasting ties and frequent contacts, and also the highest support levels. The friend-focused networks are small and focused on friendship ties, with moderate durability, frequent contact and residential proximity between members, and low levels of intimacy. Finally, the diffuse tie network, with a diverse composition, is the largest and the least intimate, presenting low levels of interchange, support and relational durability. Litwin and Landau ${ }^{23}$ confirmed these four types of networks in a sample of 192 people aged $75+$. The kin network was associated with a higher level of support and the family intensive network with the lowest level. This typology proved to be a good predictor of expected social support. 


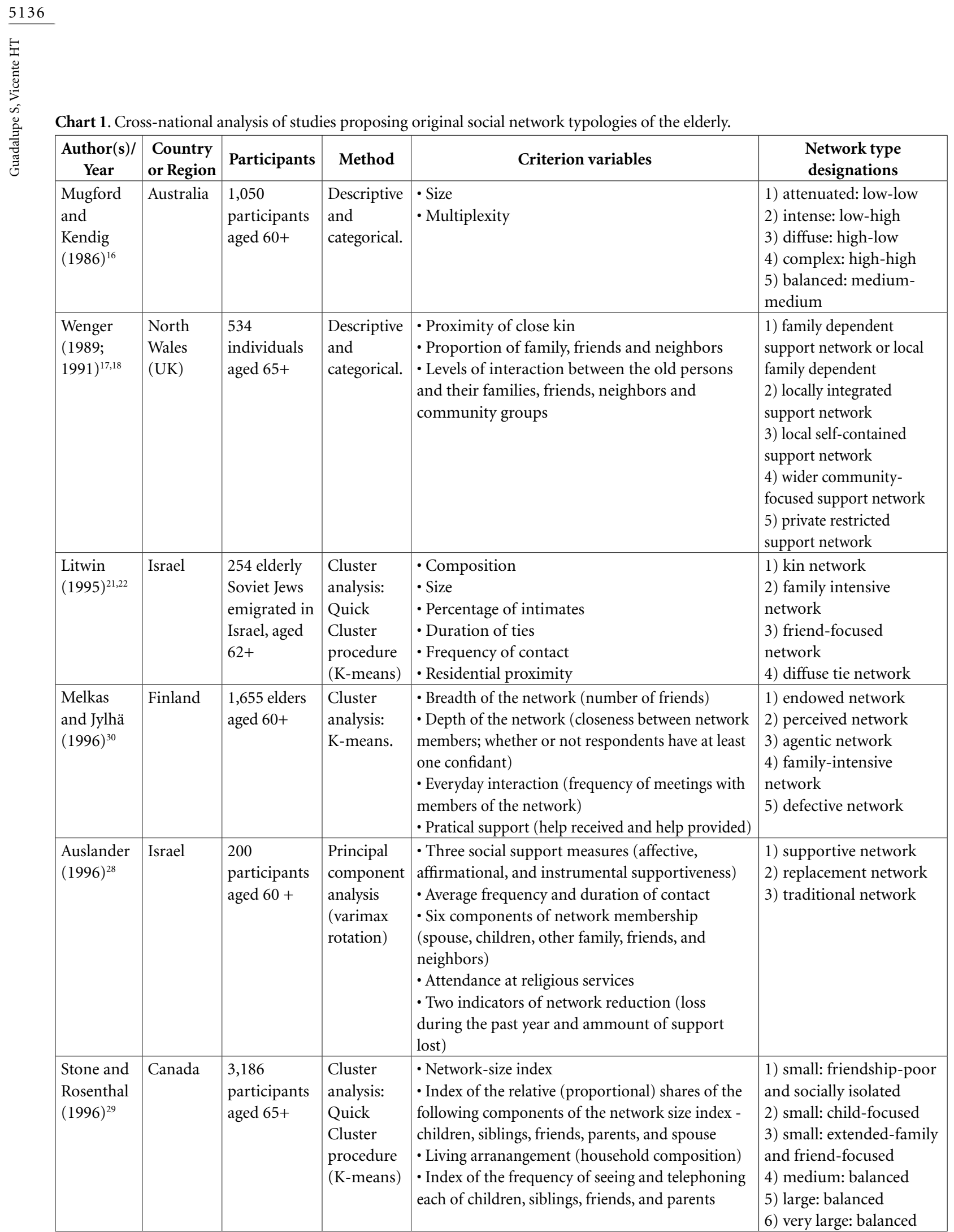

it continues

Litwin $^{24}$ also proposes a new typology from a study with 4,214 Israeli elders, aged 60+, with six types of networks: 1) diversified support network;
2) friends-and-neighbours-based support network; 3) narrow family-focused network; 4) attenuated network; 5) religious family-focused network; 6) 
Chart 1. Cross-national analysis of studies proposing original social network typologies of the elderly.

\begin{tabular}{|c|c|c|c|c|c|}
\hline $\begin{array}{c}\text { Author(s)/ } \\
\text { Year }\end{array}$ & \begin{tabular}{|c|}
$\begin{array}{c}\text { Country } \\
\text { or Region }\end{array}$ \\
\end{tabular} & Participants & Method & Criterion variables & $\begin{array}{l}\text { Network type } \\
\text { designations }\end{array}$ \\
\hline $\begin{array}{l}\text { Litwin } \\
(1997)^{24}\end{array}$ & Israel & $\begin{array}{l}4,214 \\
\text { Israelite } \\
\text { elders, aged } \\
60+\end{array}$ & $\begin{array}{l}\text { Cluster } \\
\text { analysis: } \\
\text { K-means. }\end{array}$ & $\begin{array}{l}\text { - Married } \\
\text { - Number of proximate children } \\
\text { - Frequency of sibling contact } \\
\text { - Frequency of friend contact } \\
\text { - Having a helpful neighbor } \\
\text { - Frequency of synagogue attendance }\end{array}$ & $\begin{array}{l}\text { 1) diversified support } \\
\text { network } \\
\text { 2) friends-and-neighbour- } \\
\text { based support network } \\
\text { 3) narrow family-focused } \\
\text { network } \\
\text { 4) attenuated network } \\
\text { 5) religious family- } \\
\text { focused network } \\
\text { 6) traditional extended } \\
\text { family network }\end{array}$ \\
\hline $\begin{array}{l}\text { Litwin } \\
(2001)^{26}\end{array}$ & Israel & $\begin{array}{l}\text { 2,079 elderly } \\
\text { Jews in Israel } \\
\text { aged } 60+\end{array}$ & $\begin{array}{l}\text { Cluster } \\
\text { analysis: } \\
\text { K-means. }\end{array}$ & $\begin{array}{l}\text { - Current marital status } \\
\text { - Number of adult children residing in the elder's } \\
\text { vicinity } \\
\text { - Frequency of contact on the part of the elder } \\
\text { with his or her adult children } \\
\text { - Frequency of contact with friends } \\
\text { - Frequency of contact with neighbors } \\
\text { - Frequency of attendance at a synagogue } \\
\text { - Frequency of attendance at a social club }\end{array}$ & $\begin{array}{l}\text { 1) diverse network } \\
\text { 2) friends network } \\
\text { 3) neighbours network } \\
\text { 4) family network } \\
\text { 5) restricted network }\end{array}$ \\
\hline $\begin{array}{l}\text { Fiori et al. } \\
(2006)^{31}\end{array}$ & USA & $\begin{array}{l}1,669 \text { adults } \\
\text { aged } 60+\end{array}$ & $\begin{array}{l}\text { Cluster } \\
\text { analysis: } \\
\text { K-means. }\end{array}$ & $\begin{array}{l}\text { - Married } \\
\text { - Number of children } \\
\text { - Contact with children } \\
\text { - Religious services attendance } \\
\text { - Contact with friends } \\
\text { - Meetings attendance } \\
\end{array}$ & $\begin{array}{l}\text { 1) nonfamily-restricted } \\
\text { 2) nonfriends } \\
\text { 3) family } \\
\text { 4) diverse } \\
\text { 5) friends }\end{array}$ \\
\hline $\begin{array}{l}\text { Fiori et al. } \\
(2007)^{32}\end{array}$ & $\begin{array}{l}\text { Berlin, } \\
\text { Germany }\end{array}$ & \begin{tabular}{|l}
516 older \\
adults aged \\
$70+$
\end{tabular} & $\begin{array}{l}\text { Cluster } \\
\text { analysis: } \\
\text { K-means. }\end{array}$ & $\begin{array}{l}\text { - Married } \\
\text { - Total network size } \\
\text { - Proportion in Berlin } \\
\text { - Frequency of contacts: family } \\
\text { - Frequency of contacts: friends } \\
\text { - Number of activities } \\
\text { - Proportion: close others } \\
\text { - Instrumental support } \\
\text { - Emotional support } \\
\text { - Satisfaction with family or friends }\end{array}$ & $\begin{array}{l}\text { 1) diverse-supported } \\
\text { 2) family focused } \\
\text { 3) friend focused- } \\
\text { supported } \\
\text { 4) friend focused- } \\
\text { unsupported } \\
\text { 5) restricted-nonfriends- } \\
\text { unsatisfied } \\
\text { 6) restricted-nonfamily- } \\
\text { unsupported }\end{array}$ \\
\hline $\begin{array}{l}\text { Cheng et } \\
\text { al. }(2009)^{33}\end{array}$ & China & $\begin{array}{l}1,005 \text { older } \\
\text { adults aged } \\
59+\end{array}$ & $\begin{array}{l}\text { Cluster } \\
\text { analysis: } \\
\text { K-means. }\end{array}$ & $\begin{array}{l}\text { - Total network size } \\
\text { - Frequency of contact with immediate kin } \\
\text { - Support exchange with immediate kin } \\
\text { - Frequency of contact with distant kin } \\
\text { - Support exchange with distant kin } \\
\text { - Frequency of contact with non-kin } \\
\text { - Support exchange with non-kin } \\
\text { - Engagement in social activity }\end{array}$ & $\begin{array}{l}\text { 1) diverse } \\
\text { 2) friend focused } \\
\text { 3) restricted } \\
\text { 4) family focused } \\
\text { 5) distant family }\end{array}$ \\
\hline
\end{tabular}

traditional extended family network. The diversified support network was the most represented in the sample, associated with marriage and parenting, with more significant support potential and variety. The second type is similar to the diversified networks, but with little contact and closeness with children and other relatives, more frequent among unmarried individuals. In the third type, we find frequent contacts with children and siblings living nearby, fewer contacts with neighbours and acquaintances, and limited community participation, with support from close relatives, 
Chart 1. Cross-national analysis of studies proposing original social network typologies of the elderly.

\begin{tabular}{|c|c|c|c|c|c|}
\hline $\begin{array}{c}\text { Author(s)/ } \\
\text { Year }\end{array}$ & $\begin{array}{c}\text { Country } \\
\text { or Region }\end{array}$ & Participants & Method & Criterion variables & $\begin{array}{l}\text { Network type } \\
\text { designations }\end{array}$ \\
\hline $\begin{array}{l}\text { Doubova } \\
\text { et al. } \\
(2010)^{35}\end{array}$ & México & $\begin{array}{l}4,190 \text { older } \\
\text { adults aged } \\
60+\end{array}$ & $\begin{array}{l}\text { Cluster } \\
\text { analysis: } \\
\text { K-means. }\end{array}$ & $\begin{array}{l}\text { - Total number of family members } \\
\text { - Having a life partner } \\
\text { - Having children } \\
\text { - Having friends } \\
\text { - Belonging to a community group } \\
\text { - Frequency of contact with family and friends }\end{array}$ & $\begin{array}{l}\text { 1) diverse with } \\
\text { community participation } \\
\text { 2) diverse without } \\
\text { community participation } \\
\text { 3) widowed } \\
\text { 4) nonfriends-restricted } \\
\text { 5) nonfamily-restricted }\end{array}$ \\
\hline $\begin{array}{l}\text { Litwin and } \\
\text { Shiovitz- } \\
\text { Ezra } \\
(2011)^{27}\end{array}$ & USA & $\begin{array}{l}\text { 1,462 elderly } \\
\text { Americans } \\
\text { aged } 60+\end{array}$ & $\begin{array}{l}\text { Cluster } \\
\text { analysis: } \\
\text { K-means. }\end{array}$ & $\begin{array}{l}\text { - Current marital status } \\
\text { - Number of children } \\
\text { - Number of close relatives } \\
\text { - Number of friends } \\
\text { - Frequency of getting together with neighbors } \\
\text { - Frequency of attendance at religious services } \\
\text { - Frequency of attendance at organized group } \\
\text { meetings }\end{array}$ & $\begin{array}{l}\text { 1) diverse network } \\
\text { 2) friend network } \\
\text { 3) congregant network } \\
\text { 4) family network } \\
\text { 5) restricted network }\end{array}$ \\
\hline $\begin{array}{l}\text { Cabral et } \\
\text { al. }(2013)^{36}\end{array}$ & Portugal & $\begin{array}{l}999 \\
\text { participants } \\
\text { aged } 50+\end{array}$ & $\begin{array}{l}\text { Descriptive } \\
\text { and } \\
\text { categorical. }\end{array}$ & $\begin{array}{l}\cdot \text { Size } \\
\cdot \text { Composition }\end{array}$ & $\begin{array}{l}\text { 1) small predominantly } \\
\text { familial network } \\
\text { 2) small predominantly } \\
\text { nonfamily network } \\
\text { 3) big predominantly } \\
\text { familial network } \\
\text { 4) big predominantly } \\
\text { nonfamily network }\end{array}$ \\
\hline $\begin{array}{l}\text { Burholt } \\
\text { and Dobbs } \\
(2014)^{37}\end{array}$ & $\begin{array}{l}\text { UK, India } \\
\text { and } \\
\text { Bangla- } \\
\text { desh }\end{array}$ & $\begin{array}{l}590 \\
\text { participants } \\
\text { aged } 55+\end{array}$ & $\begin{array}{l}\text { Cluster } \\
\text { analysis: } \\
\text { K-means. }\end{array}$ & $\begin{array}{l}\text { - Network size } \\
\text { - Proportion of the network classified by gender, } \\
\text { age, kin and non-kin } \\
\text { - Proximity (living in the participant's household } \\
\text { or not) } \\
\text { - Formal help }\end{array}$ & $\begin{array}{l}\text { 1) multigenerational } \\
\text { households: older } \\
\text { integrated networks } \\
\text { 2) multigenerational } \\
\text { households: younger } \\
\text { family networks } \\
\text { 3) family and friends } \\
\text { integrated networks } \\
\text { 4) non-kin restricted } \\
\text { networks }\end{array}$ \\
\hline $\begin{array}{l}\text { Park et al. } \\
(2014)^{38}\end{array}$ & $\begin{array}{l}\text { South } \\
\text { Korea }\end{array}$ & $\begin{array}{l}4,251 \text { South } \\
\text { Korean } \\
\text { seniors aged } \\
65+\end{array}$ & $\begin{array}{l}\text { Cluster } \\
\text { analysis: } \\
\text { two-step } \\
\text { cluster. }\end{array}$ & $\begin{array}{l}\text { - Marital status } \\
\text { - Social activities } \\
\text { - Family size } \\
\text { - Physical proximity to children } \\
\text { - Frequency of contact with children } \\
\text { - Frequency of contact with friends } \\
\text { - Support from children and family } \\
\end{array}$ & $\begin{array}{l}\text { 1) restricted type } \\
\text { 2) couple-focused type } \\
\text { 3) friend type } \\
\text { 4) diverse type }\end{array}$ \\
\hline $\begin{array}{l}\text { Park et al. } \\
(2015)^{39}\end{array}$ & USA & $\begin{array}{l}1,092 \text { older } \\
\text { Korean } \\
\text { immigrants } \\
\text { in Florida } \\
\text { and New } \\
\text { York aged } \\
60+\end{array}$ & $\begin{array}{l}\text { Latent class } \\
\text { analysis }\end{array}$ & $\begin{array}{l}\text { - Marital status } \\
\text { - Living arrangement } \\
\text { - Number of close family members } \\
\text { - Frequency of contact with close family } \\
\text { members } \\
\text { - Number of close friends } \\
\text { - Frequency of contact with close friends } \\
\text { - Participation in religious meetings } \\
\text { - Participation in organized meetings }\end{array}$ & $\begin{array}{l}\text { 1) diverse } \\
\text { 2) unmarried/diverse } \\
\text { 3) married/co-residence } \\
\text { 4) family focused } \\
\text { 5) unmarried/restricted } \\
\text { 6) restricted }\end{array}$ \\
\hline $\begin{array}{l}\text { Li and } \\
\text { Zhang } \\
(2015)^{34}\end{array}$ & China & $\begin{array}{l}4,190 \text { older } \\
\text { Chinese } \\
\text { aged } 64+\end{array}$ & $\begin{array}{l}\text { Cluster } \\
\text { analysis: } \\
\text { K-means. }\end{array}$ & $\begin{array}{l}\text { - Current marital status } \\
\text { - Number of close children } \\
\text { - Frequency of playing cards and/or mahjong } \\
\text { - Frequency of attending organized social } \\
\text { activities } \\
\text { - Support from family } \\
\text { - Support from friends/neighbors }\end{array}$ & $\begin{array}{l}\text { 1) diverse } \\
\text { 2) friend } \\
\text { 3) family } \\
\text { 4) restricted }\end{array}$ \\
\hline
\end{tabular}

Source: Elaborated by the authors. 
being more frequent among married individuals. In the attenuated network, we find older persons without spouses, centred in the interaction with close children (their only support), scant contact with other interpersonal relations and little community participation. The fifth type has similar characteristics but a higher level of involvement with religious practice. The sixth type is associated with married people and large offspring, supporting children and other relatives living nearby. A greater diversity of ties and resources in networks is associated with greater autonomy and health ${ }^{25}$.

Another study by Litwin ${ }^{26}$, with 2,079 older Jews in Israel, listed five types of networks: 1) diverse network; 2) friends network; 3) neighbours network; 4) family network; 5) restricted network. Diverse networks are the most frequent in the sample, composed of relatives, friends, and neighbours, with a high rate of contacts. Individuals with these networks are usually married, male, younger and with children living nearby. Friends networks are also frequent. They are similar to diverse networks, but contact with neighbours is minimal. Neighbours networks have a higher contact frequency with children and neighbours; they are associated with individuals without a spouse, predominantly women. There are frequent contacts with nearby children and regular religious practice in family networks but minimal contacts with neighbours and friends. Finally, restricted networks have the most limited set of social ties, with limited contact with adult children and no contact with friends or neighbours; they are more frequent among older people with no spouse.

In a more recent study, with 1,462 older Americans, Litwin and Shiovitz-Ezra ${ }^{27}$ confirmed most network types identified by Litwin's previous studies: 1) diverse network; 2) friend network; 3) congregant network; 4) family network; 5) restricted network. The authors confirmed the dominant characteristics of each type of network, though the congregant network replaced the neighbours' network of the previous study. Individuals with networks belonging to the congregant type attend religious services more regularly, interacting with other congregations in places of worship. The restricted network was associated with lower social capital and greater social risk, while the diverse, congregant and friend networks were associated with higher social capital and well-being.

Another study in Israel is presented by Auslander ${ }^{28}$. We included this study with a relatively small sample mainly because it included several support measures and loss of network members (and their support) among the criterion vari- ables used to differentiate social networks. These variables significantly influenced the factor analysis results and the selection of the terms used to identify the three network types that emerged, finding no parallel in the literature. Supportive networks were characterized by affirmational, affective and instrumental supportiveness, and average frequency of contacts. This type of network was associated with younger and more highly educated respondents, with good physical capacity and a positive mental state. Replacement networks were characterized by the loss of a network member (usually family members or friends) in the previous year and loss of support, but also with an increasing number of friends (an indicator of network regeneration), and were associated with younger women of Israeli origin. Finally, the presence of a spouse, number of children and synagogue attendance typify the traditional network, which was found more frequently in men of Eastern origin, with a positive mental state and good physical capacity.

Stone and Rosenthal ${ }^{29}$ identified six network profiles in their study of Canada's elderly, with gender differences among network types (men are evenly distributed, whereas women show an irregular distribution). Findings from this study also identified vulnerable groups with fewer interpersonal resources, namely those with fragile network structures: small - friendship-poor and socially isolated and small - extended-family and friend-focused. The first type of network is characterized by a proportion of friends and levels of interaction with children below average. Men and women with these networks are vulnerable because they must cope with the double effects of small network size and lack of contact with the few network members available. Due to their small size, it seems likely that they have fewer children, which underlines its structural fragility. The small extended-family and friend focused networks are small and dominated by siblings and friends. Women with these networks are less likely to have a spouse, which added to the absence of children, might indicate lifelong singles. This type of network is particularly relevant because it reminds us of the growing prevalence of childless elderly in countries with decreasing fertility rates and its influence on network structure and interactions.

In Finland, Melkas and Jylhä ${ }^{30}$ propose five types of networks: 1) endowed network; 2) perceived network; 3) agentic network; 4) family-intensive network; 5) defective network. The first type is characterized by friendships, frequent 
extra-family contacts, active mutual support and heterogeneity. The second differentiates itself from the former due to a lower frequency of extra-family contacts. The third has a widespread extra-family interaction with different types of people and high levels of support, both provided and received. In the fourth type, the relationship between parents and children plays a central role. Finally, the fifth network type is smaller, composed chiefly of childless individuals, with a reduced number of friends and no neighbours, presenting higher isolation levels.

Fiori et al..$^{31}$ developed a study with 1,669 North American adults aged 60+ and found five types of network: 1) diverse, 2) family, 3) friends, 4) nonfamily, and 5) nonfriends. These last types are two kinds of restricted networks. The nonfamily network presents the most limited social ties, belonging to unmarried or childless individuals. The nonfriends network type has a low frequency of contact with friends and low social participation, which are the opposite characteristics of the friends network. The family network was the least prevalent type, focusing on relations with children. The diverse network was the most frequent in the sample and the most extensive of all networks. Individuals with nonfriends networks manifest the highest levels of depressive symptomatology, whereas those with diverse networks obtain the lowest. These results illustrate the correlation between network type (and the support quality associated) and mental health. Comparing the two restricted types regarding their relation to depressive symptoms, the authors conclude that "absence of family in the context of friends is less detrimental than the absence of friends in the context of family"31 (p.25).

Another study from Fiori et al. ${ }^{32}$, conducted in Berlin (Germany) with 516 older adults aged $70+$, reported six different network types: 1) diverse-supported; 2) family focused; 3) friend focused-supported; 4) friend focused-unsupported; 5) restricted-nonfriends-unsatisfied; 6) restricted-nonfamily-unsupported. The most prevalent was the third type, and the least prevalent was the sixth. The first type is an extensive network, with high emotional support, a high frequency of contact and social activities. The second usually belongs to married individuals with frequent family contact. The third type consisted of unmarried individuals with emotional and instrumental support. Those with the fourth type are also unmarried but have low levels of support. The fifth type consisted of unmarried elderly with small networks, low activity and support. The sixth type has a similar profile to the previous but with small nonlocal networks and infrequent family contact. The authors also found significant differences in well-being across network types. Consistent with previous research was the finding of high levels of well-being among individuals with diverse-supported networks, with the opposite trend in the restricted types. But results also questioned the linear relation between the presence of friends in the network and well-being expounded earlier, even though the authors attribute the low levels of well-being found in the friend-focused network to the fact that individuals with this type were older, less active and received more instrumental support, probably due to their greater need for help. Thus, relations between network type and health/well-being outcomes seem more complex than they appeared at first sight.

In the context of China, the study by Cheng et al..$^{33}$ focused the social networks and subjective well-being of 1,005 older adults, identifying five types of networks: 1) diverse; 2) friend focused; 3) restricted; 4) family focused; 5) distant family. Diverse networks were the most frequent, followed by friend focused and distant family, the least frequent being family focused and restricted networks. Diverse networks are the largest and obtain the best indicators of support and frequency of contacts. Diverse and friend focused networks are associated with higher levels of well-being, while restricted networks are associated with lower levels, echoing the aforementioned studies. This study also suggests the relevance of extended family support among Chinese older people, especially in the absence of children and close relatives.

A more recent study in China was developed by Li and Zhang ${ }^{34}$, based on a sample of the Chinese Longitudinal Healthy Longevity Survey, with 4,190 participants. This study indicates four types of networks, very similar to the previous study: 1) diverse; 2) friend; 3) family; 4) restricted. A diverse network has the most balanced social resources; it is associated with marriage, social activities, urban environments and better health. A friend network focuses on extra-family relationships and has a high frequency of social activities, such as mah-jong. Family networks are centred on kinship, with close children, and are more frequent among rural women. Restricted networks are the most common and have the most negative values across the evaluated dimensions (e.g. subjective health and psychological well-being), being associated with older individ- 
uals and rural environments. One of the major contributions of this study, however, was that it estimated not only the way social networks influence health, but also the effects of health status on social milieu, i.e., it considered the reciprocal association between these two sets of variables. This allowed the authors to conclude that even though diverse networks yield the most beneficial health outcomes, the "decrease in all health indicators leads to withdrawal from more-beneficial network types such as a diversified network type, and a shift to less-beneficial network types such as family-focused or restricted networks" ${ }^{34}$ (p.59). Li and Zhang ${ }^{34}$ also underline the importance of these results regarding social policy debate in one of the fastest aging countries globally. They propose measures to break health/social network vicious cycles and promote virtuous ones, namely the deployment of more resources by community organizations to organize social activities, facilitate the participation of older people with physical limitations and encourage those with poor psychological conditions to engage in these activities and interact with a diversified group of people.

A study in Mexico, by Doubova et al..$^{35}$, with a sample of 3,348 participants, presents yet another different typology. Their analyses identified five types of networks: 1) diverse with community participation, 2) diverse without community participation, 3) widowed, 4) nonfriends-restricted, 5) nonfamily-restricted. Diverse networks without community participation were the most frequent in the sample, followed by widowed networks. The less frequent was the nonfamily-restricted network. The first type includes family and friends, with frequent contacts and community participation. The second has the same characteristics but with no participation in a community structure. The third comprises widowed people with children, an average frequency of contact with children and friends, and no participation in the community setting. In the fourth type, all elderlies have children and an extended family, with whom they have frequent contacts; however, it does not include friends, and there is little community participation. The fifth is common among childless older persons, with a reduced number of relatives and a low frequency of contacts centred in friendship relations. Widowed and restricted types are associated with negative self-rated health, dependency and depression.

In the Portuguese context, a study by Cabral et al. ${ }^{36}$ presents a typology based on size and composition. The study has 999 participants aged 50+, focused on relations of trust (sharing important issues, concerns or problems), distinguishing four types of networks: 1) small predominantly familial networks; 2) small predominantly nonfamily networks; 3) big predominantly familial networks; 4) big predominantly nonfamily networks. The first ones are the most frequent and the latter the least frequent. The first type is characterized by the proximity between its members and longer relative duration of ties; the second, by older network members and greater distance between them and the focal person; the third, by younger members, whom the respondent has known for a relatively long time, and greater satisfaction; the fourth type is characterized by lower tie duration, greater residential dispersion and lower satisfaction. In those networks where family predominates, the geographic proximity increases. Smaller networks also present proximity, more long-lasting relationships, and higher satisfaction levels with their most significant members. In the predominantly nonfamily networks, neighbourhood and friendship relations stand out, but geographic dispersion increases and satisfaction decreases; these nonfamily networks are mainly composed of older members, whereas intergenerational relationships with children and grandchildren strongly influence predominantly familiar ones.

Burholt and Dobbs ${ }^{37}$ studied the social support networks of 590 participants aged 55+ in the context of multigenerational migrant households living in the UK and South Asia (India and Bangladesh) belonging to ethnic minorities. The authors propose four network types: 1) multigenerational households: older integrated networks; 2) multigenerational households: younger family networks; 3) family and friends integrated networks; 4) non-kin restricted networks. The first ones are mainly composed of relatives and some friends, and usually belong to older individuals, married and living with their families, with active participation in the local community. The second type is centred on family relationships, involving married or widowed individuals with little community involvement. The third type is very small, focused on the domestic environment and conjugality, with regular religious practices. The fourth type integrates a higher number of non-relatives, and are more isolated, typical of childless older persons living alone or only with their spouses, with formal support. This study specifically addressed of cultural heterogeneity and ethnic diversity (people living in Western countries but belonging to ethnic minorities or those living in non-Western countries), arguing 
that most network typologies have been developed to fit the "majority" in Western societies. The authors consider that multigenerational living arrangements, common in certain familistic cultures, could impact the classification of network type. In these cases, the frequency of contacts tends to increase, and distance decreases solely because some network members co-reside. As a result, individuals from these cultural backgrounds might fall within the premises of a robust network type, overestimating their levels of well-being and underestimating formal service needs. The typology proposed by Burholt and Dobbs ${ }^{37}$ is able to differentiate migrants and non-migrants, and distinguishes two types of networks with intergenerational co-residence in common. Also relevant were the results indicating that if Wenger's typology discussed earlier were to be used, only a small minority of South Asian elders would have fallen in the vulnerable private-restricted networks (4.2\%), signalling the likely need for formal services support. In contrast, the new typology classified nearly a fifth of the study sample $(18.2 \%)$ in the restricted nonkin networks, the most vulnerable in terms of loneliness and isolation.

Park et al. ${ }^{38}$ present a typology with four types of networks, built from a sample of 4,251 South Korean seniors, in the scope of the Korean Longitudinal Study of Aging: 1) restricted;2) couple-focused; 3) friend; 4) diverse. The first type is characterized by the geographical proximity to children and limited contact with friends, comprising older urban men with social participation. The second type comprises younger and more educated married subjects, with children and a large family, though geographically distant, and low community participation. The third type is dominated by friend relations, presenting a high level of contact with children and friends, and high community participation; it is mostly composed of women. The fourth type presents the greatest extent and diversity of ties, but a lower level of support, mostly healthy and active women. The most frequent networks are friend $(35 \%)$ and couple-focused (27\%); about a fifth of the respondents are embedded in restricted networks (22\%), and these report lower well-being and higher depressive symptomatology when compared to all others. Results also showed a marked prevalence of two network types with limited social relations (restricted and couple-focused), that might indicate a specific pattern of South Korean elderly, which in turn may contribute to contemporary social issues in the country, such as the elevated prevalence of depression and high suicide rates. Another significant finding was the absence of a conventional family centred type. Although socially restricted, the couple-focused type presents high levels of life satisfaction and low levels of depressive symptomatology, indicating the uniqueness of this network type among South Korean elderly, and the compensatory role that spouse/partner appears to possess, limiting the detrimental effects of a less diverse and active social network.

A study of Park et al..$^{39}$, with 1,092 older Korean immigrants in Florida and New York (United States), agglomerate six types of networks: 1) diverse; 2) unmarried/diverse; 3) married/coresidence; 4) family focused; 5) unmarried/restricted; 6) restricted. The married/coresidence and the diverse type were the most frequent. The group of individuals being married and not living alone maintained medium levels of the other social network variables. The majority of the diverse network subjects were also married and lived with others, with frequent contact with close family and friends, maintaining community participation, namely in religious meetings. With less than $10 \%$ of the sample, the restricted type report to individuals with minimal contacts with family and friends and minimal involvement in a religious group. Contrarily, the family-focused network has a high contact frequency and is highly involved in religious activities. The unmarried/restricted type included those who were not married and likely to live alone, with closer relationships with friends than family and minimal religious participation. The unmarried/diverse type was the less frequent, similar to the diverse type, but living alone. The diverse network is related to better health and lower depressive symptoms, whereas the unmarried/restricted has the opposite results. Of particular note is that no friend-centred network was found, which the authors hypothesize might be due to disruptions in social convoys due to immigration, which might be more pronounced in older versus younger migrants, and to the critical role of spouse and adult children in Asian cultures.

Regarding the geographical distribution of the studies analysed, it might be said that even though they are not restricted to Western societies, less developed countries and the southern hemisphere are clearly underrepresented, particularly Central and South America and Africa, regions where demographic aging is expected to have a significant impact in the near future. In contrast, Israel and the USA are overrepresented (Figure 1). 
Finally, regarding methodological issues, Chart 1 already showed us that the most common statistical procedure used in network typology construction is cluster analysis, but closer attention should also be paid to the discriminating criterion variables that the authors selected, mainly because these significantly influence the subsequent typology. However, this analysis could be compromised due to the variegated nature of the variables used by different authors. In this sense, the criterion variables presented in Chart 1 were classified into three major categories and thirteen subcategories. In addition, it must be noted that some of the criterion variables used were composite, encompassing more than one category/subcategory (for example, the variable "number of friends" was coded both as "size" and "composition"). The results are presented in Chart 2.

Most typologies are multidimensional and use 5 to 6 types of discriminating criterion variables (55.6\%). 22.2\% use three or four types, and $11.1 \%$ use just two. Only two studies used more than six types of variables (11.1\%). Size (88.9\%), composition $(88.9 \%)$ and frequency of contacts $(77.8 \%)$ are the most used types of criterion variables, which accounts for the fact that most typologies explicitly mention the composition of the network in the terms used to designate different types. However, it should be noted that these results stem from the fact network composition is frequently analysed through composite variables, i.e., those that include other types of network variables such as frequency of contacts and social support (e.g. support from children and frequency of contact with friends).

Besides the frequency of contacts, the most recurrent functional/interactional or contextual type of variable was social participation (61.1\%), followed by social support (38.9\%), geographic dispersion $(27.8 \%)$ and intimacy/closeness in $16.7 \%$ of the studies. Multiplexity and duration of ties appeared in only one study each. In the category "others", marital status stands out, appearing in half the studies. In two studies, living arrangements were a criterion variable; network reduction and satisfaction with relationships appeared only once.

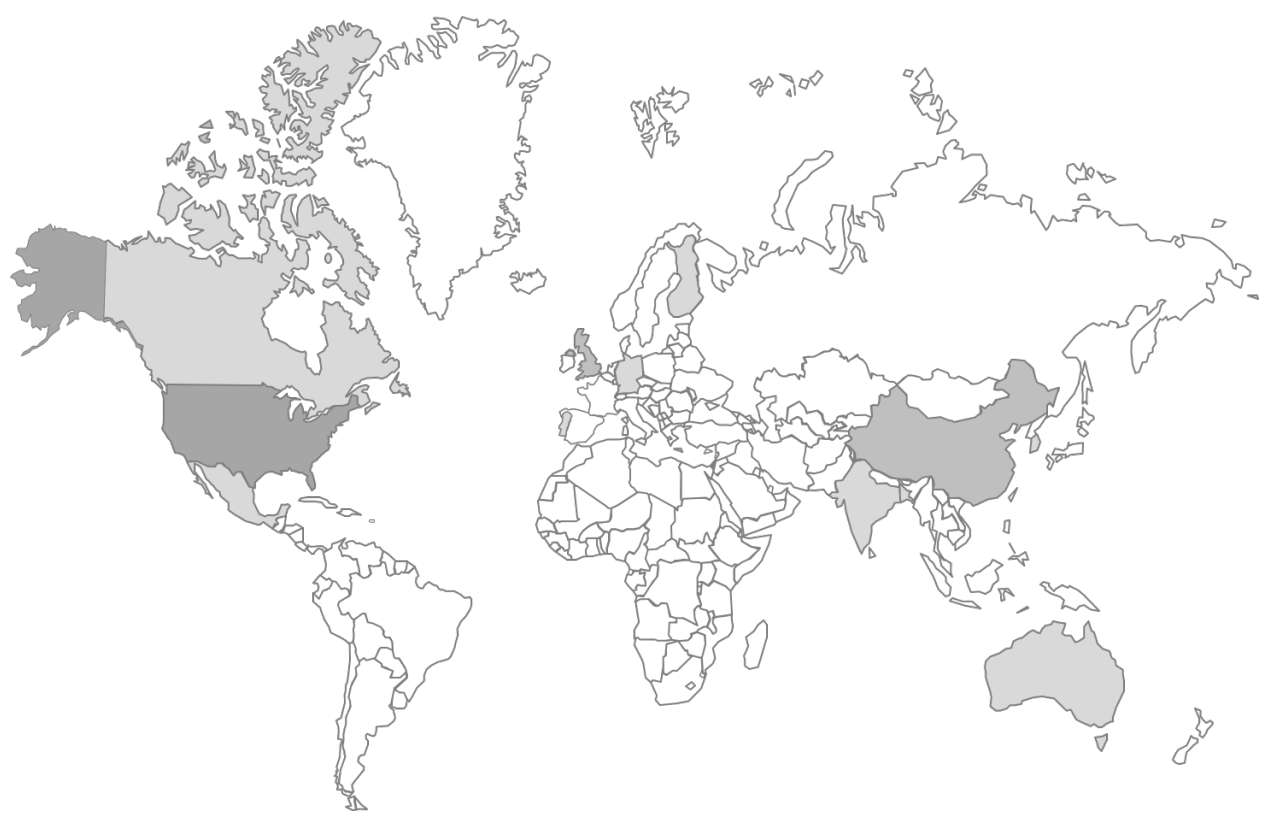

Figure 1. Geographical distribution of country/region-specific original network typologies (darker shades of grey indicate a greater number of studies). 


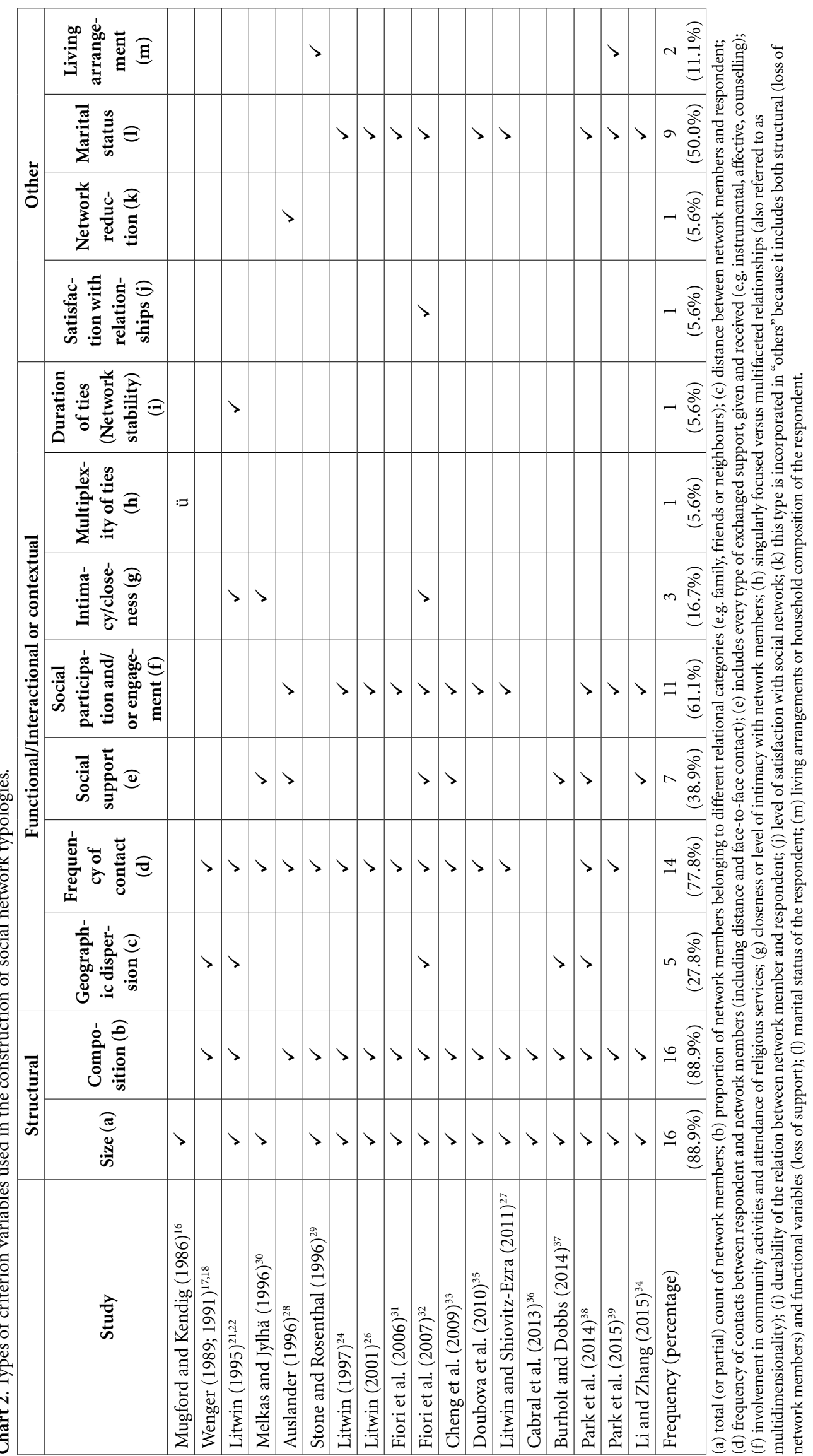

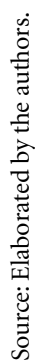




\section{Discussion}

Although we might consider that nowadays, the typology analysis of older people's social networks is not exactly a ground-breaking methodological procedure, the results of this cross-national review show a significant and burgeoning interest in the last decades by researchers from different backgrounds, regions and countries. $55.6 \%$ of the analysed studies were published between 2005 and 2015. If the treatment of network types was considered by Litwin ${ }^{40}$ as one of the most innovative contributions to social network studies in the mid-1990s, it can be said that today it is a well-established research practice that has thoroughly proven its value.

In line with the cross-national review by Litwin $^{40}$, we found that researchers rely heavily upon morphological/structural and interaction$\mathrm{al} /$ functional criteria when constructing network typologies $12,16,18,21-23,29,30,34,35,37,38,41$. However, it should be noted that studies that include less frequent criterion variables, such as loss of network members ${ }^{28}$ or satisfaction with social relations ${ }^{32}$, yield substantially different typologies that enrich the theoretical debate regarding social networks in old age.

Most studies' methodology followed the guidelines regarding the inductive construction from data clustering, using a multivariate $\mathrm{K}$-means cluster analysis ${ }^{12,21-23,29-32,34,35,37,41}$. This statistical procedure is essentially exploratory because the researcher must prescribe the number of clusters and try several solutions before opting for one, usually guided by the goodness of fit with pre-existing theories or typological proposals found in the literature ${ }^{26}$ and additional statistical analyses ${ }^{32,38}$. It must be noted, however, that these preliminary analyses in search for the most robust cluster combination should also be guided by the final models' capacity in addressing the defining features of the specific country/ region (cultural and/or socio-economic) where the study is developed and the idiosyncrasies of the target population, in order to improve their heuristic value and ability to identify vulnerable groups. Thus, for example, in the Cheng et al. study ${ }^{33}$ the choice of the appropriate number of clusters to extract was guided by statistical analysis (eta square from multivariate analysis of variance showing the strength of the relationship between clusters and criterion variables), the number of cases in each cluster and, as we argue, the meaningfulness of the formed clusters.

Despite the frequent inclusion of structural and interactional variables network type differentiation, the evaluation of these variables varies substantially, depending on the nature of the instruments used to collect data. Most studies resorted to questionnaires with closed-ended and scaled-response questions, self or hetero-administered through an interview. Other studies used social network assessment inventories explicitly designed for that purpose $e^{18,21-23,33,36,42-45}$. Finally, there were some studies that used data collected in population census or general social surveys ${ }^{29,30}$. We can find several means to the same end, but this variety inevitably limits the scope of cross-national comparisons. Also, some of the reviewed studies do not specify the probe question or network generator associated with the establishing network boundaries. As Stone and Rosentha ${ }^{29}$ put it, setting boundaries to a network (i.e. the definition of which members are to be included) is a "thorny issue", mainly because it involves a certain degree of arbitrariness. In this sense, it is essential to understand that the information derived from network studies is intimately dependent on the definition of social networks and the method adopted by the researcher ${ }^{46-48}$. Moreover, some studies are unclear regarding the approach used to network delineation (for example, if it was an interactive, relational, affective, exchange approach or a combination of these ${ }^{49}$ ). Also worth mentioning are the differences between assessment inventories. For example, some instruments allow the respondent to identify as many network members as they wish, whereas others restrict the maximum number of persons that an individual can include ${ }^{21,22,36}$. This issue is particularly relevant when comparing network size across different studies.

Despite the different cultural backgrounds of the reviewed studies, it was possible to find several commonalities, both in the terms used to identify different network types and in their respective characteristics. Regarding the terms used, we found that they frequently reference the social network composition (e.g. friend-focused 
or family-intensive), although including other characteristics (e.g. supportive or defective).

Family relationships emerge as the core of social networks in later life $\mathrm{f}^{50,51}$, and most of the reviewed typologies mention different types of family-centred networks. Some typologies even highlight family subsystems, living conditions of conjugality or marital status, such as multigenerational households' networks ${ }^{37}$, widowhood networks $s^{35}$ or conjugal networks $s^{38}$. Community participation and social activities, especially of a religious nature, also emerged as a defining feature of several network types.

Restricted networks emerged in 11 typologies, and diverse networks were included in 10 typologies. These two types were associated, respectively, with less and more effective social support and were also predictors of negative or positive dimensions of well-being, health and mental health ${ }^{25,27,30,33-35,37,39}$ and of negative and positive aspects of social support and participa-

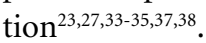

Several studies showed significant interactions between social network type, health and well-being. Therefore, identification of social network types might be relevant for practitioners, signalling social vulnerabilities, identifying support needs and anticipating life trajectories $^{32}$. Many authors argue that one of the main reasons underlying social network typology construction resides in its potential to foster social policy debate ${ }^{34,40}$. Indeed, the high prevalence of family, couple and/or children-focused networks highlights the necessity of social services providing families (especially spouses and children) with the necessary means to care for their elderly relatives. On the other hand, the salutogenic properties found in the more diverse networks, i.e., those including friends and neighbours, underscores the concomitant need to support community services efforts directed at expanding older people's social networks.

Also relevant was the finding that some countries/regions are grossly underrepresented. Indeed, although studies have been conducted in many other countries not referenced in this review, these tend to resort to typologies created in foreign economic and socio-cultural contexts (e.g. Thiyagarajan et $\mathrm{al}^{20}$ ). As we have seen, the construction of network typologies needs to be solidly grounded in the ethnic/cultural specificities of the target population to avert the risk of underestimating the number of elders at risk, and their social service needs ${ }^{37}$.

\section{Conclusions}

This paper presented the results of a non-systematic literature review about social network typologies for the older population that included 18 studies with large samples from 14 countries worldwide. Even though this type of study dates back to the 1980s, several original network typologies for the elderly were recently proposed, highlighting its relevance in providing guidelines to anticipate aging trajectories and support needs, identifying social risk, planning and tailoring interventions, informing professionals and social services providers about emerging needs and their diversification, as well as contributing to social policy debate. Across this extended time interval of 30 years, several commonalities were central to social network typologization in the older population: network size, network composition (namely the proportion and type of family ties), marital status, frequency of contacts and community participation or engagement.

Several reviewed studies identified restricted and diverse network types associated, respectively, with less and more effective social support features. These network types were also good predictors of well-being, health, mental health, social support and social participation. Finally, this review also identified the relevance of considering cultural and environmental context-specificities when constructing social network typologies. Cross-nationally, more studies are needed, especially in developing countries and emerging economies. 


\section{Collaborations}

S Guadalupe: substantial contribution to the study design, literature review, data analysis, discussion, drafting the article, and final approval of the version to be published. HT Vicente: substantial contribution to the study design, data analysis, discussion, drafting the article, critical revision, and final approval of the version to be published.

\section{References}

1. Barnes JA. Class and committees in a Norwegian island parish. Human Relations 1954; 7:39-58.

2. Bott E. Conjugal roles and social networks. Human Relations 1955; 8:345-384.

3. Merton RK. Social Theory and Social Structure. New York: The Free Press; 1968.

4. Bott E. Familia e red social. Madrid: Altea Taurus; 1990.

5. Guay J. L'intervenant professionnel face à l'aide naturelle. Ottawa: Gaëtan Morin Éditeur; 1984.

6. Granovetter M. The strength of weak ties. Am J Sociol 1973; 78:1360-1380.

7. Guèdon M-C. Les réseaux sociaux. In: Brodeur C, Rousseau $\mathrm{R}$, organizadores. L'intervention de réseaux - une pratique nouvelle. Montréal: Éditions France -Amérique; 1984. p. 15-33.

8. Wellman B. The community question: The intimate networks of East Yorkers. Am J Sociol 1979; 84(5):1201-1231.

9. Kellerhals J, McClusley H. Uma topografia subjectiva do parentesco. Contributo para o estudo das redes de parentesco nas famílias urbanas. Sociol Problemas Práticas 1988; 5:171-189.

10. Portugal S. Quanto vale o capital social? O papel das redes informais na provisão de recursos. In: Fontes B, Martins $\mathrm{PH}$. organizadores. Redes, práticas associativas e gestão pública. Recife: Ed. Universitária da UFPE; 2006.

11. Portugal S. Famílias e redes sociais. Ligações fortes na produção de bem-estar. Coimbra: Almedina; 2014.

12. Giannella E, Fischer CS. An inductive typology of egocentric networks. Soc Networks 2016; 47:15-23.

13. Vassilev I, Rogers A, Kennedy A, Wensing M, Koetsenruijter J, Orlando R, Portillo MC, Culliford D. Social network type and long-term condition management support: a cross-sectional study in six european countries. PLoS One 2016; 11(8):e0161027.

14. Kendig HL. Ageing and families: A support network perspective. Sydney: Allen and Unwin Ltd; 1986.

15. Noguchi J. The science review article - An opportune genre in the construction of science. Linguistic Insights Volume 17. Bern: Peter Lang; 2006.

16. Mugford S, Kendig H. Social relations: Networks and ties. In: Kendig H, editor. Ageing and families: A social networks perspective. Sydney: Allen and Unwin; 1986. p. 38-59.

17. Wenger GC. Support networks in old age: constructing a typology. In: Jefferys M, editor, Growing Old in the Twentieth Century. London: Routledge; 1989. p. 169-185.

18. Wenger GC. A network typology: from theory to practise. J Aging Stud 1991; 5(2):147-162.

19. Wenger GC, Davies R, Shahtahmasebi S, Scott A. Social isolation and loneliness in old age: review and model refinement. Ageing Soc 1996; 16(3):333-358.

20. Thiyagarajan JA, Prince M, Webber M. Social support network typologies and health outcomes of older people in low and middle income countries - A 10/66 Dementia Research Group population-based study. Int Rev Psychiatr 2014; 26(4):476-485.

21. Litwin $\mathrm{H}$. The social networks of elderly immigrants: An analytic typology. J Aging Stud 1995; 9(2):155-174. 
22. Litwin H. Unprooted in old age: soviet Jews and their social networks in Israel. Westport, CT: Praeger; 1995.

23. Litwin H, Landau R. Social network type and social support among the old-old. J Aging Stud 2000; 14(2):213-228.

24. Litwin H. Support network type and health service utilization. Res Aging 1997; 19:274-299.

25. Litwin H. Social network type and health status in a national sample of elderly Israelis. Soc Sci Med 1998; 46(4-5):599-609.

26. H. Social network type and morale in old age. Gerontologist 2001; 41(4):516-24.

27. Litwin H, Shiovitz-Ezra S. Social network type and subjective well-being in a national sample of older Americans. Gerontologist 2011; 51:379-388.

28. Auslander G. The Interpersonal Milieu of Elderly People in Jerusalem. In: Litwin H, editor. The Social Networks of Older People: A Cross-National Analysis. London: Praeger; 1996. p. 77-97.

29. Stone L, Rosenthal C. Profiles of the social networks of Canada's elderly: An analysis of 1990 General Social Survey Data. In: Litwin H, editor. The Social Networks of Older People: A Cross-National Analysis. Westport: Praeger Publishers; 1996. p. 77-97.

30. Melkas T, Jylhä M. Social network characteristics and social network types among Eldery People in Finland. In: Litwin H, editor. The social network of older people: a cross national analysis. Westport, СT: Praeger; 1996. p. 99-116.

31. Fiori KL, Antonucci TC, Cortina KS. Social Network Typologies and Mental Health Among Older Adults. J Gerontol 2006; 61B(1):25-32.

32. Fiori KL, Smith J, Antonucci TC. Social network types among older adults: a multidimensional approach. $J$ Gerontol B Psychol Sci Soc Sci 2007; 62(6):322-330.

33. Cheng S-T, Lee CKL, Chan ACM, Leung EMF, Lee J-J. Social network types and subjective well-being in chinese older adults. J Gerontol Psychol Sci 2009; 64B(6):713-722.

34. Li T, Zhang Y. Social network types and the health of older adults: Exploring reciprocal associations. Soc Sci Med 2015; 30(130):59-68.

35. Doubova SV, Pérez-Cuevas R, Espinosa-Alarcón P, Flores-Hernández S. Social network types and functional dependency in older adults in Mexico. BMC Public Health 2010; 10:104.

36. Cabral MV, Ferreira PM, Silva PA, Jerónimo P, Marques T. Processos de envelhecimento em Portugal - Usos do tempo, redes sociais e condições de vida. Lisboa: Fundação Francisco Manuel dos Santos; 2013.

37. Burholt V, Dobbs C. A support network typology for application in older populations with a preponderance of multigenerational households. Ageing Soc 2014; 34:1142-1169.

38. Park S, Smith J, Dunkle RE. Social network types and well-being among South Korean older adults. Aging Mental Health 2014; 18(1):72-80.
39. Park NS, Jang Y, Lee BS, Ko JE, Haley WE, Chiriboga DA. An Empirical Typology of Social Networks and Its Association With Physical and Mental Health: A Study With Older Korean Immigrants. J Gerontol Series B Psychol Sci Soc Sci 2015; 70(1):67-76.

40. Litwin H. A Cross-National Social Network Analysis. In: Litwin H, editor. The Social Networks of Older People: A Cross-National Analysis. London: Praeger; 1996. p. 205-221.

41. Guadalupe S. As redes de suporte social informal em Serviço Social: as redes sociais pessoais de idosos portugueses nos processos de avaliação diagnóstica em respostas sociais [thesis] Lisboa: ISCTE-IUL; 2017.

42. Cochran M, Larner M, Riley D, Gunnarsson L, Henderson C Jr. Extending Families: The Social Networks of Parents and Their Children. Cambridge: Cambridge University Press; 1990.

43. McCallister L, Fischer CS. A Procedure for Surveying Personal Networks. Sociol Methods Res 1978; 7(2):131-148.

44. Antonucci TC, Akiyama H. Social networks in adult life and a preliminary examination of the convoy model. J Gerontol 1987; 42(5):519-527.

45. Kahn RL, Antonucci TC. Convoys over the life course: Attachment, roles, and social support. In: Baltes PB, Brim O, editors. Life-span development and behavior. San Diego: Academic Press; 1980. p. 253-286.

46. Molina JL. El análisis de redes sociales. Una introducción. Barcelona: Bellaterra; 2001.

47. Tracy EM, Catalano RE, Whittaker JK, Fine D. Reliability of social network data. Soc Work Res Abstracts 1990; 26(2):33-35.

48. Wellman B. Are personal communities local? A Dumptarian reconsideration. Soc Networks 1996; 18(4):347-354.

49. Van der Poel MGM. Delineating personal support networks. Soc Networks 1993; 15:49-70.

50. MP. Envelhecimento - Estado da arte. Coimbra: Imprensa da Universidade de Coimbra; 2010.

51. Phillipson C, Bernard M, Phillips J, Ogg J. The family and community life of older people. Social networks and social support in three urban areas. London, New York: Routledge; 2001.

Article submitted 30/04/2019

Approved 18/11/2019

Final version submitted 20/11/2019

Chief editors: Romeu Gomes, Antônio Augusto Moura da Silva 